\title{
PROFITABILITY ANALYSIS OF URBAN MASS TRANSPORT LINES USING ACTIVITY-BASED COSTING METHOD: AN EVIDENCE FROM THE CZECH REPUBLIC
}

\author{
Boris Popesko* \\ Tomas Bata University in Zlin, Faculty of Management and Economics, Czech Republic \\ Roman Zamečnik, \\ Tomas Bata University in Zlin, Faculty of Management and Economics, Czech Republic \\ Andrea Kolkova, \\ University of Entrepreneurship and Law, Czech Republic
}

The objective of this study is to present how could be Activity-Based Costing method used for the purpose of the profitability analysis of individual bus and trolleybus lines in an urban mass transport company which operates the land public transport inside the medium sized town in Czech Republic. Activity-Based Costing method had been used, in order to causal allocation of overhead costs to individual operations in order to measure the profitability of particular transport lines. The performed study showed the application process of the Activity-Based Costing and possible information outputs for an urban mass transport company as well as the limitations of the method use in the field of transportation services. The study also analyses the obstacles in effective data collection and processing which implementation team faced during the analysis. The primary limitation of the analysis, is similarly as in other studies, is the quality of the non-financial information which had to be obtained. Study discusses problems related with the fare system, which does not provide the information regarding the route taken by individual passenger. The study presents the how could be ABC method used for the decision making support in urban mass transport company and shows a real example of the $A B C$ system information outputs.

Key words: Activity-Based Costing, Urban mass transport, Profitability, Overhead cost allocation

\section{INTRODUCTION}

Profitability analysis focused on decentralized business units is one of the essential roles of traditional management accounting (Drury 2001, Garrison et al. 2010). The objective of such analysis is to provide managers and decision makers with information, which may help then to make appropriate decisions. Another role of the decentralized unit profitability analysis is to provide accurate information on the profit generated by the individual segments of the business. In recent decades we can observe more intensive initiatives in application of various managerial techniques in different kind of service organizations. They often rely on profitability analyses, performance measurement or accurate costing techniques in order to support decision-making process, allow the profitability increase and heighten the cost efficiency of the various performing activities.
One of the greatest obstacles related to the profitability analyses is the ability to perform accurate cost assignment using a proper overhead cost allocation process. The ability to accurately gauge the profitability of given cost objects, which ultimately contribute to overall organizational profitability, is highly dependent on the accuracy of the costing method applied. Traditionally used costing methods, such as absorption costing, are often criticized for the inaccuracy and various limitations. Those shortages or limitations had been very closely described by many authors (Drury 2001, Kaplan and Johnson 1987). It is widely known that traditional costing methods sums all overhead cost together and allocate them via simplified average-based procedure. On the other hand accounting reports normally do not provide management interpretation of the relations between the cost and cost 
objects. Strong criticism of the traditional costing systems was presented by Kaplan and Johnson (1987). Despite that criticism, traditional costing methods are still frequently used in practice, mostly because of their simplicity and low data input requirements. The limitations of traditional costing methods could be more crucial when applying costing systems in service organizations. Rotch (1990) defined several reasons why cost allocation and implementing a costing system in a service organization might turn out to be more complicated.

The problems associated with traditional costing methods resulted in the introduction of ActivityBased Costing (ABC), firstly presented by Kaplan and Johnson (1987). ABC uses logical cost allocation procedure, where the overhead cost of organization are allocated to the products via defined structure of activities. Important difference between traditional costing and $A B C$ is that overhead costs are not allocated using an inaccurate allocation base, but through the activities actually performed within an organization. $A B C$ significantly improved the accuracy of cost allocation, as well as facilitating measurement of the outputs of organizational activities.

In general, $A B C$ is based on the simple presumption that performed services consume activities that in turn consume resources (Goldberg 2011). Generally, ABC requires two stages: a. costs are allocated to activities; b. said activities are allocated to a product or service (Baker, 1998). In other words, if it is possible to measure the cost of activities and estimate the consumption of such activity outputs by an individual cost object, then allocating the true cost accurately via the actual causal factors is facilitated. Wodchis (1999) stated that traditional costing techniques allocate costs to all units based on an average unit cost, or they pool indirect costs and allocate them to services, this in proportion to the volume of services or direct costs. Andrade (1999) states that $A B C$ more precisely reflects the costs of operations in a company; doing so in a more consistent manner than traditional methods. The biggest disadvantage presented in many studies is that traditional methods of cost accounting could over- or underestimate the costs of services, as overhead costs could vary with the complexity of delivering services and not due to the volume of services. (Hankins, 2004; Lucey, 2002). In order to more accurately determine the efficiency of an ABC model, a traditional cost accounting system has to be utilized in parallel (Agyar, 2007).

Utilization of the $A B C$ system usually results in collecting accurate data on profitability or facilitates precise analysis for covering the costs of the analyzed cost objects, such as the transport lines in the case of urban mass transport company. Early applications of the Activity-Based Costing approach in the industry sector (Innes and Mitchell, 1990; Glad and Becker, 1996) have been followed by many applications in the service (Tsai and Kuo, 2004), logistics (Baykasoglu and Kaplanoglu, 2007; Everaert et al., 2008), healthcare (Udpa, 1996) and other specific areas. But the direct application of $A B C$ to urban mass transport companies is not a frequent case in the literature.

Nevertheless, initiating $A B C$ in service organizations is hampered by several serious limitations, such as the high complexity of the system, which makes it difficult to actually utilize, creating extreme demands for non-financial information (Stouthuysen et al., 2009). Everaert et al. (2008) claim that many managers who have tried to implement $A B C$ in their organizations, have abandoned the attempt in the face of rising costs and irritation on the part of employees.

Despite the fact, that $A B C$ brings many advantages for the decision making process, the application of $A B C$ to a service organization, especially to urban mass transport, includes several challenges which do not generally exist for $A B C$ applications in manufacturing organizations. Some of these problems was discussed by Rotch (1990) on the case of a logistic company. These arguments could be accepted also for application of $A B C$ in urban mass transportation: Output is harder to define; In many cases determining activities and cost drivers is not straightforward; Data collection and measurements is more complicated than manufacturing; Activity in response to service requests may be less predictable. Joint capacity represent a high portion of total cost and is difficult to link output related activities.

Performing the effective profitability analysis, using $A B C$, in the conditions of urban mass transport company is very specific due to the above mentioned reasons. One of the important issues that limit the utilization of $A B C$ for profitability analysis purposes in this conditions is the fact that urban mass transport companies usually do not operate in fully competitive environment. 
Companies operating the urban mass transit usually provide their services in a highly regulated environment (Poliak 2013). De Borger et al. (2002) point at that government intervention in the sector is widespread and has traditionally been justified by reference to a series of market failures. In the past two decades, however, concerns about possible regulatory failures have led to a reassessment of the role of the state in the organization in the sector.

One of the primary objectives of every service provider is to achieve the efficiency of the existing operations. Elementary efficiency in the operations could be generally measured by the quantity of the output and the inputs consumed, which could be quantified as the company costs (Drury, 2001; Král, 2006), in other words, when production proceeds at the lowest possible perunit cost.

Efficiency and profitability analysis in the conditions of urban mass transport companies are, despite these simple relations, restricted for several reasons. Firstly, the companies which operate the urban mass transport usually work with a very complicated structure of customers, lines, services and other cost objects. Secondly, the fare technology usually does not allow obtaining the information about the passenger behavior, which means that the company is unable to get the information about the specific route taken by individual passenger. And thirdly, the above described government and municipality intervention in a non-competitive field usually causes the inability of management of urban mass transport companies to apply any progressive programs to reduce the costs or increase the effectiveness of existing operations.

\section{METHODS}

As mentioned above, main objective of the study was to analyze the profitability of the operated public transport bus and trolleybus lines within the city of Zlín. Most important component of performed profitability analysis was to precisely assign the cost and revenues to the individual operated lines. Analyzed company, which was chosen for carrying out this analysis, operates the land urban mass transport using busses and trolleybuses within the territory of Zlín (population 100 000). The reason why this company was chosen is the fact that the company started dealing with more accurate cost allocation based on the $A B C$ techniques.

The company operates 13 trolleybus lines, 11 bus lines, and cooperates with the national provider of the passenger rail transport. Besides the major transport services, the company also provides other additional services: an advertising agency and repair services for trolleybuses. The company owns 65 trolleybuses and 45 busses.

The following table presents the basic information about the company performance in years $2008-2010$. The financial data are transformed from CZK currency in fixed exchange rate of 25 CZK per EURO. Income from the transportation service is calculated as the sum of all types of fare including the time coupons. The number of passengers was calculated as the sum of individual fares sold and estimated volume of 4 rides a day per time coupons. It was expected that each holder of monthly or yearly coupon made in average four rides a day. Data from the fiscal year 2010 had been used in the profitability measurement.

Table 1: Basic data of Zlín urban transport company. Source: Company financial statements

\begin{tabular}{|l|c|c|c||}
\hline & $\mathbf{2 0 0 8}$ & $\mathbf{2 0 0 9}$ & $\mathbf{2 0 1 0}$ \\
\hline Total Income & $€ 10129249$ & $€ 10827942$ & $€ 11169016$ \\
\hline Transport services income & $€ 4633981$ & $€ 4394259$ & $€ 4361783$ \\
\hline Municipal subsidies & $€ 3723200$ & $€ 3865139$ & $€ 3860102$ \\
\hline Other subsidies & $€ 185359$ & $€ 175770$ & $€ 174471$ \\
\hline Total Costs & $€ 10683275$ & $€ 10699588$ & $€ 11247914$ \\
\hline Profit & $-€ 554026$ & $€ 128354$ & $-€ 78817$ \\
\hline Number of passangers & 37334050 & 35934000 & 35314000 \\
\hline
\end{tabular}

As the table shows, the trend in number of passengers and income from transportation services is declining. This confirms the De Boer's
(2008) proposition about the declining trends in transport demand in most industrial economies. Hajek and Siwek (2009) also researched the 
passenger behavior in the Zlín region and conclude the growing passenger preference for individual means of transport. Table 1 also illustrates quite a large portion of municipal subsidies for the company. The fare revenues cover only $45 \%$ of the cost of transportation services. This portion is quite standard in conditions of the Czech Republic in other similar public transport operators. Values differ from $46 \%$ in Ústí nad Labem to $29 \%$ in České Budějovice (SDPCR, 2007). This situation matches the situation in developed economies. Pucher et al. (1983) features that the passengers fare covered only $42 \%$ of transit operating costs in the U.S. in the 1980's compared to $99 \%$ in 1965 and $86 \%$ in 1970 .

Prior to commencing the standard ABC application, it was necessary to gather all necessary financial and non-financial data required for performing the cost analysis. The documentation and information gathered was as follows:

- Cost reports from financial accounting for the given departments and centres

- Cost reports from management accounting for said departments and centres

- Lists of fixed assets with costs and depreciation schedules

- Technical documentation for construction work

- Overview of the employees of the departments and their salaries

- Information on non-financial indicators; e.g. statistics for the following: number of passengers, $\mathrm{km}$, consumption of electricity and fuel etc.

- Results of passenger volume observation

The calculation of the operation costs of vehicles per kilometer was not sufficient for considering the individual costs objects, defined as individual lines. For those purposes the costs and revenues of individual bus and trolleybus lines had to be estimated. The costs of the lines could be quantified based on the kilometer length of the line and the operation frequency. The revenue estimation was much more complicated because the used system of fare disallows the identification of individual passenger and route which he takes. One of the existing information inputs of the project was the observation research of passenger quantities in individual lines, which was conducted in 2008. In this research, the number of passengers using individual lines was esti- mated by the manual counting of the passenger volumes in each route by hired persons. The research output was then used for allocation of revenues for individual lines.

After the obtaining the necessary data, all typical phases of Activity-Based Costing were conducted (Drury 2001), which includes:

- Defining the structure of activities, taking into consideration simplicity of the system and consequent limited number of activities

- Allocating the cost registered in the accounting system and other additional evidence to defined activities, using varied forms of resource cost drivers

- Calculating the activity rates for the given activities, using defined cost drivers and activity output measures

- Calculating costs of bus and trolleybus lines

- Comparing operated lines cost and revenues in order to calculate the profitability

The cost calculation pertaining to the $A B C$ approach was performed in five consequential stages, as discussed in results part.

\section{RESULTS}

The initial stage of cost calculation involved defining activities that reflect significant cost pools in the given public transport operator. Four major processes were defined within the organization: mass transport services, advertising services, external and supplemental services and the support process. All processes were than disarticulated into several activities. Table 2 display the activities defined within the model. The numerical codes were also assigned to individual activities in order to facilitate the work with activities. The objective of this step was to keep the lowest possible number of activities in order to simplify the work with the data. Finally 11 primary and 4 secondary activities had been defined within the model. Such structure of the ABC model is relatively simple. Some of the activities (201, 301, 302) were defined in the way that matches the future cost object for the purpose to simplify the allocation of the activity costs to cost objects.

Once the major activities had been identified, overhead costs were allocated to these defined activities. After performing this step of $A B C$ application, it was possible to determine the total costs of activities. Allocation was made through the resource-cost drivers discerned. 
Table 2: Processes and activities defined within the model. Source: authors

\begin{tabular}{|c|l|}
\hline \multicolumn{2}{|l|}{ Process: 100 - Mass transport operation } \\
\hline 101 & Administration and support of the mass transit \\
\hline 102 & Tickets sale and distribution \\
\hline 103 & Daily service and cleaning of vehicles \\
\hline 104 & Operation of vehicles \\
\hline 105 & Ticket inspection \\
\hline 191 & Traffic network maintenance \\
\hline Process: 200 & - Advertising and promotional services \\
\hline 201 & Advertising and promotional services \\
\hline Process: 300 & - External and supplemental services \\
\hline \hline 301 & External repairs \\
\hline 302 & Charter services \\
\hline 303 & Other external services \\
\hline Process $900-$ Secondary activities \\
\hline 901 & Management and infrastructure \\
\hline 902 & Building maintenance \\
\hline 903 & Accounting and finance \\
\hline 904 & IS/lT \\
\hline
\end{tabular}

Costs were allocated to activities via several resource-cost drivers (RCD), such as the labor consumption of physicians based on activities, and the square meters of floor space given over to activities, etc. All costs were assigned to activities using the "activity cost matrix", which displays links between indirect costs and activities. According to the relatively simple structure of activities, the assignment of costs to those activities was in some cases relatively easy, because the whole cost centers could be assigned to the activities. Table 4 demonstrates the total sum of costs which were assigned to individual activities.

As we can see, most significant cost pool was related to the activity 104 - Operation of the vehicles. This sum includes all costs related to the daily operation of vehicles such as fuel and electricity consumption, salaries of the drivers of indirect material. Average consumption of the buses was from 29.26 to $49.19 \mathrm{l} / \mathrm{km}$ and consumption of trolleybuses from 139.42 to 237.87 according to the type of the vehicle.

Following phase of the cost allocation required defining cost drivers for each activity. Intensity drivers (direct allocation) were used for the allocation of activity costs to individual cost objects in most cases. Table 5 presents the selected cost drivers used for the allocation of activity costs to cost objects. No specific allocation relations were defined within the mass transport services (process 100), so number of the total kilometers of all vehicles had been used as the cost driver. This cost driver was used also as the general cost driver for most of the activities as the most suitable reason for cost consumption. Only activities where the different cost drivers were defined are traffic network maintenance, which is performed only in connection with trolleybus transport, and the ticket inspection, which was measured individually. For the traffic network maintenance, the total number of trolleybus kilometers was chosen as the cost driver. After the definition of the cost drivers the output measure of the individual activities had to be determined. Output measure quantifies the number of cost drivers consumed in specific time period. After completing the above stages, it was possible, on the basis of this information, to calculate the unit costs of activities - activity rates; in this phase primary rates. These could be calculated by simple division of the total activity cost by the activity output measure determined. Activity rates can be worked out by the single formula:

\section{Activity rate $=$ total activity cost $/$ activity output measure}


Table 3: Calculation of the total cost of an activity using the activity cost matrix

\begin{tabular}{|c|c|c|c|c|c|c|}
\hline & activity 1 & activity 2 & activity 3 & $\ldots$ & activity n & $\begin{array}{c}\text { Total of cost } \\
\text { elements }\end{array}$ \\
\hline \hline cost element 1 & $\mathrm{X}_{1} \cdot{ }^{*} \mathrm{~K}_{11}$ & $\mathrm{X}_{1} \cdot{ }^{*} \mathrm{~K}_{12}$ & $\mathrm{X}_{1} \cdot{ }^{*} \mathrm{~K}_{13}$ & $\ldots$ & $\mathrm{X}_{1} \cdot{ }^{*} \mathrm{~K}_{1 \mathrm{n}}$ & $\mathrm{X}_{1} \cdot$ \\
\hline cost element 2 & $\mathrm{X}_{2} \cdot{ }^{*} \mathrm{~K}_{21}$ & $\mathrm{X}_{2} \cdot{ }^{*} \mathrm{~K}_{22}$ & $\mathrm{X}_{2} \cdot{ }^{*} \mathrm{~K}_{23}$ & $\ldots$ & $\mathrm{X}_{2} \cdot{ }^{*} \mathrm{~K}_{2 n}$ & $\mathrm{X}_{2} \cdot$ \\
\hline cost element 3 & $\mathrm{X}_{3} \cdot{ }^{*} \mathrm{~K}_{31}$ & $\mathrm{X}_{3} \cdot{ }^{*} \mathrm{~K}_{31}$ & $\mathrm{X}_{3} \cdot{ }^{*} \mathrm{~K}_{33}$ & $\ldots$ & $\mathrm{X}_{3} \cdot{ }^{*} \mathrm{~K}_{3 n}$ & \\
\hline$\ldots$ & $\ldots$ & $\ldots$ & $\ldots$ & $\ldots$ & $\ldots$ & \\
\hline cost element $\mathrm{m}$ & $\mathrm{X}_{\mathrm{m}} \cdot / \mathrm{K}_{\mathrm{m} 1}$ & $\mathrm{X}_{\mathrm{m}} \cdot / \mathrm{K}_{\mathrm{m} 2}$ & $\mathrm{X}_{\mathrm{m}} \cdot / \mathrm{K}_{\mathrm{m} 3}$ & $\ldots$ & $\mathrm{X}_{\mathrm{mn}} / \mathrm{K}_{\mathrm{mn}}$ & $\mathrm{X}_{\mathrm{m}} \cdot$ \\
\hline Total of activity & $\mathrm{X}_{\cdot 1}$ & $\mathrm{X}_{\cdot 2}$ & $\mathrm{X}_{\cdot 3}$ & $\ldots$ & $\mathrm{X} \cdot \mathrm{n}$ & $\mathrm{X} .$. \\
\hline
\end{tabular}

$\mathrm{X}_{\mathrm{i}}$ - - total of cost element $\mathrm{i}$

$\mathrm{K}_{\mathrm{ij}}$ - key to the division of $\mathrm{i}$-th cost element and $\mathrm{j}^{- \text {th }}$ activity in $\%$

Table 4: List of activities and assigned primary activity costs. Source: authors

\begin{tabular}{|c|c|l|c|}
\hline Process & \multicolumn{2}{|l|}{ Activitiy } & Activity cost \\
\hline $\mathbf{1 0 0}$ & \multicolumn{2}{|l|}{ Mass transport services } & $€ \mathbf{9 4 4 5} \mathbf{0 9 5}$ \\
\hline & $\mathbf{1 0 1}$ & Administration and support of the MT & $€ 413676$ \\
\hline & $\mathbf{1 0 2}$ & Tickets sale and distribution & $€ 288334$ \\
\hline & $\mathbf{1 0 3}$ & Daily service and cleaning of vehicles & $€ 613451$ \\
\hline & $\mathbf{1 0 4}$ & Operation of vehicles & $€ 5548458$ \\
\hline & $\mathbf{1 0 5}$ & Ticket inspection & $€ 484825$ \\
\hline & $\mathbf{1 9 1}$ & Traffic network maintananace & $€ 483027$ \\
\hline & $\mathbf{1 9 2}$ & Repair of vehicles & $€ 1613323$ \\
\hline $\mathbf{2 0 0}$ & Advertising services & $€ \mathbf{1 1 2 6 4 8}$ \\
\hline & 201 & Advertising and promotional services & $€ 112648$ \\
\hline $\mathbf{3 0 0}$ & External and supplemental services & $€ \mathbf{8 0 9} \mathbf{0 0 1}$ \\
\hline & 301 & External repairs & $€ 575254$ \\
\hline & 302 & Charter services & $€ 23987$ \\
\hline & 303 & Other external services & $€ \mathbf{8 7 7} 723$ \\
\hline $\mathbf{9 0 0}$ & Support activities & $€ 307659$ \\
\hline & 901 & Management and infrastructure & $€ 345594$ \\
\hline & 902 & Building maintenance & $€ 159019$ \\
\hline & 903 & Accounting and finance & $€ 65451$ \\
\hline
\end{tabular}

Table 5: List of activity cost drivers, output measures and primary rates of activities. Source: Authors

The following step of the calculation is the allocation of secondary activity cost to defined primary activities. This step is an essential part of all ABC systems, while the secondary activities cannot be directly traced to the cost objects. Secondary activities had to be assigned to the primary activities using the known allocation procedures (Glad and Becker, 1996). Selected cost drivers, such as square meters or account entries, were used for the allocation of those secondary activity costs. Table 6 shows the recalculated primary activity costs after the allocation of secondary activities. The combined rate is calculated as the sum of primary rates and secondary rates. The second- ary rate represents the consumption of secondary activity costs by unit of primary activity.

This step included calculating the costs of a selected cost object, i.e. a patient. In order to assign the cost to a defined cost object, it was necessary to identify the volumes of individual activity outputs consumed by a specific bus or trolleybus route. Information about the cost consumed by the operated lines obtainable from the information system of the company using number of total travelled kilometers. 
Table 5: List of activity cost drivers, output measures and primary rates of activities. Source: Authors

\begin{tabular}{|c|c|c|c|c|c|}
\hline Activiti & & Total activity costs & Cost driver & Output measure & Primary rate \\
\hline \multicolumn{2}{|c|}{ Mass transport services } & $€ 9445095$ & & & \\
\hline 101 & Administration and support of the MT & $€ 413676$ & number of total $\mathrm{km}$ of all vehicles & 4814970 & $€ 0,086$ \\
\hline 102 & Tickets sale and distribution & $€ 288334$ & number of total $\mathrm{km}$ of all vehicles & 4814970 & $€ 0,060$ \\
\hline 103 & Daily service and cleaning of vehicles & $€ 613451$ & number of total $\mathrm{km}$ of all vehicles & 4814970 & $€ 0,127$ \\
\hline 104 & Operation of vehicles & $€ 5548458$ & number of total $\mathrm{km}$ of all vehicles & 4814970 & $€ 1,152$ \\
\hline 105 & Ticket inspection & $€ 484825$ & direct alloacation & $\mathrm{N} / \mathrm{A}$ & \\
\hline 191 & Traffic network maintananace & $€ 483027$ & number of total $\mathrm{km}$ of trolley-buses & 3131373 & $€ 0,154$ \\
\hline 192 & Repair of vehicles & $€ 1613323$ & number of total $\mathrm{km}$ of all vehicles & 4814970 & $€ 0,335$ \\
\hline \multicolumn{2}{|c|}{ Advertising services } & $€ 112648$ & & & \\
\hline 201 & Advertising and promotional services & $€ 112648$ & direct allocation & N/A & \\
\hline \multicolumn{2}{|c|}{ External and supplemental services } & $€ 809001$ & & & \\
\hline 301 & External repairs & $€ 575254$ & number of hours & 30250 & $€ 19,017$ \\
\hline 302 & Charter services & $€ 23987$ & number of $\mathrm{km}$ & 11250 & $€ 2,132$ \\
\hline 303 & Other external services & $€ 209761$ & direct alloacation & $\mathrm{N} / \mathrm{A}$ & \\
\hline \multicolumn{2}{|c|}{ Support activities } & $€ 877723$ & & & \\
\hline 901 & Management and infrastructure & $€ 307659$ & primary activity costs & 259168603 & $€ 0,001$ \\
\hline 902 & Building maintenance & $€ 345594$ & square meters & 19810,98 & $€ 17,445$ \\
\hline 903 & Accounting and finance & $€ 159019$ & account entries & 7608 & $€ 20,901$ \\
\hline 904 & IS/IT & $€ 65451$ & number of computers & 70,00 & $€ 935,013$ \\
\hline
\end{tabular}

Table 6: Total activity costs after allocation of secondary activity costs. Source: authors

\begin{tabular}{|c|c|c|c|c|c|}
\hline Process & Activitiy & & Total activity costs & Output measure & Secondary rate \\
\hline \multirow[t]{8}{*}{100} & \multicolumn{2}{|c|}{ Mass transport services } & $€ 10199883$ & & \\
\hline & 101 & Administration and support of the MT & $€ 468165$ & 4814970 & $€ 0,097$ \\
\hline & 102 & Tickets sale and distribution & $€ 330263$ & 4814970 & $€ 0,069$ \\
\hline & 103 & Daily service and cleaning of vehicles & $€ 702381$ & 4814970 & $€ 0,146$ \\
\hline & 104 & Operation of vehicles & $€ 5784352$ & 4814970 & $€ 1,201$ \\
\hline & 105 & Ticket inspection & $€ 506927$ & $\mathrm{~N} / \mathrm{A}$ & \\
\hline & 191 & Traffic network maintananace & $€ 550412$ & 3131373 & $€ 0,176$ \\
\hline & 192 & Repair of vehicles & $€ 1857383$ & 4814970 & $€ 0,386$ \\
\hline \multirow[t]{2}{*}{200} & \multicolumn{2}{|c|}{ Advertising services } & $€ 126139$ & & \\
\hline & 201 & Advertising and promotional services & $€ 126139$ & $\mathrm{~N} / \mathrm{A}$ & \\
\hline \multirow[t]{4}{*}{300} & \multicolumn{2}{|c|}{ External and supplemental services } & $€ 918445$ & & \\
\hline & 301 & External repairs & $€ 639388$ & 30250 & $€ 21,137$ \\
\hline & 302 & Charter services & $€ 38005$ & 11250 & $€ 3,378$ \\
\hline & 303 & Other external services & $€ 241052$ & $\mathrm{~N} / \mathrm{A}$ & \\
\hline
\end{tabular}

After the performing of all necessary steps the calculation of the profitability of individual operated lines could be performed. The first output of the model was the cost calculations of the individual cost objects, in this case the mileage costs per kilometer travelled by vehicle. These costs could be easily quantified as the sum of combined rates of activities, which are used for the performance of urban mass transport. This means activities 101, 102, 103, 104 and 192 for buses and activities 101, 102, 103, 104, 191 and 192 for trolley busses. The sum of costs per km is then $€ 1.9$ for busses and $€ 2.07$ for trolley busses. In comparison, the $\mathrm{km}$ cost for charter services is $€ 3.38$. The calculation of the operation costs of vehicles per kilometer was not sufficient for considering the individual costs objects, defined as individual lines. The costs of the lines could be quantified based on the kilometer length of the line and the operation frequency. The revenue estimation was based on the field analysis of passenger quantities in individual lines, which was conducted in 2008. In this study, the number of passengers in individual lines was determined based on this performed analysis. The research output was then used for allocation of revenues for individual lines. 


\begin{tabular}{|c|c|c|c|c|c|c|c|c|c|c|c|c|c|c|c|c|c|c|c|}
\hline 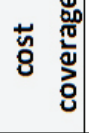 & & 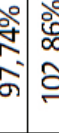 & 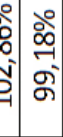 & 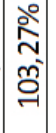 & 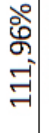 & 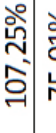 & 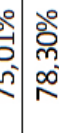 & $\mid \begin{array}{c}0 \\
0 \\
0 \\
o b \\
0 \\
0\end{array}$ & $\begin{array}{l}0 \\
\vdots \\
\vdots \\
\vdots \\
\vdots\end{array}$ & & 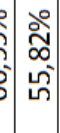 & 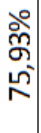 & & |c & 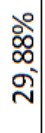 & 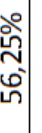 & & 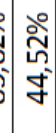 & \\
\hline 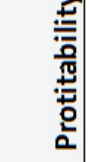 & & 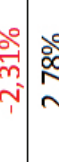 & 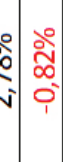 & $\mid \begin{array}{c}\stackrel{\circ}{\hat{n}} \\
\mathrm{~m} \\
\mathrm{~m}\end{array}$ & $\begin{array}{c}\text { s. } \\
\text { s. } \\
\text { - } \\
\text { - }\end{array}$ & \begin{tabular}{l|l} 
\\
$\vdots$ \\
$\vdots$ \\
0
\end{tabular} & 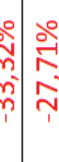 & 客 & 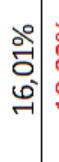 & 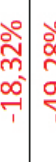 & 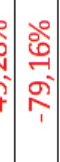 & $\begin{array}{l}\text { वें } \\
\text { के }\end{array}$ & & 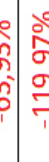 & $\begin{array}{l}0 \\
0 \\
0 \\
\tilde{\tilde{f}} \\
\hat{7}\end{array}$ & ז & & 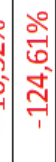 & \\
\hline 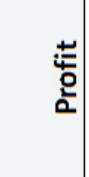 & & 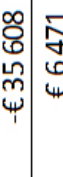 & 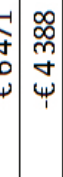 & 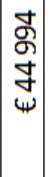 & 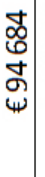 & 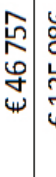 & 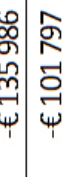 & & 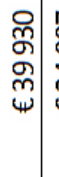 & 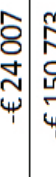 & 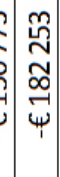 & 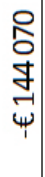 & 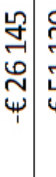 & 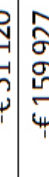 & $\begin{array}{l}\begin{array}{l}\exists \\
g \\
g \\
\psi\end{array}\end{array}$ & 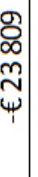 & & & \\
\hline 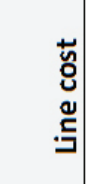 & & 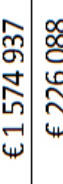 & 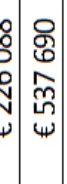 & 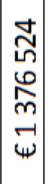 & 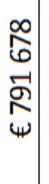 & 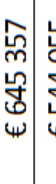 & 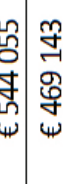 & 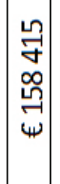 & 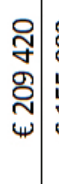 & 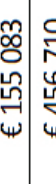 & 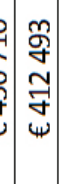 & 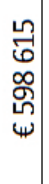 & 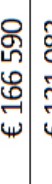 & 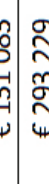 & 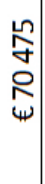 & 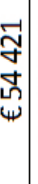 & & & 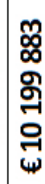 \\
\hline$\frac{\xi}{\circ}$ & 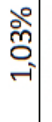 & ปે̀ & 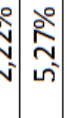 & 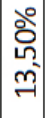 & 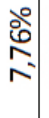 & 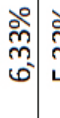 & 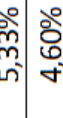 & 今. & 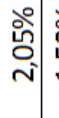 & خิ̀ & 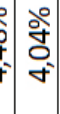 & $\begin{array}{c}\text { مें } \\
\text { o. } \\
\text { ஸे }\end{array}$ & 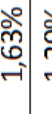 & 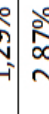 & $\begin{array}{l}\text { ఫें. } \\
\text { ठ. }\end{array}$ & 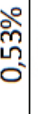 & & & ठें \\
\hline 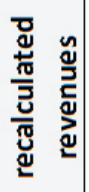 & 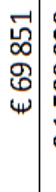 & 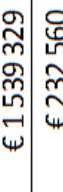 & 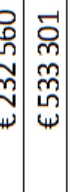 & 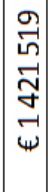 & $\begin{array}{c}\mathbb{W} \\
0 \\
0 \\
0 \\
\infty \\
w\end{array}$ & 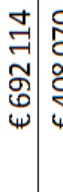 & 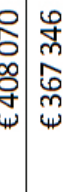 & 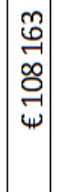 & 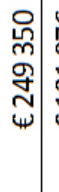 & & 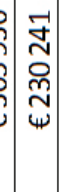 & 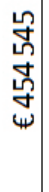 & 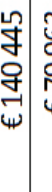 & 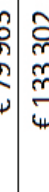 & 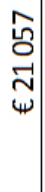 & 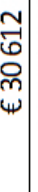 & & 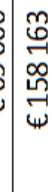 & 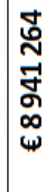 \\
\hline $\begin{array}{l}\bar{\Xi} \\
\stackrel{0}{0} \\
\bar{y} \\
0 \\
0 \\
0 \\
0\end{array}$ & & 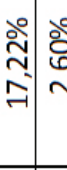 & 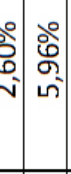 & 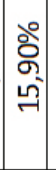 & ڤัे & 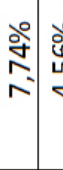 & 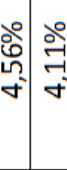 & 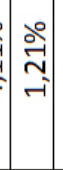 & \begin{tabular}{l} 
今े \\
సे \\
\multirow{2}{*}{}
\end{tabular} & 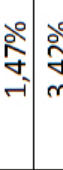 & $\begin{array}{l}n \\
\end{array}$ & $\begin{array}{l}\text { वें } \\
0 \\
\text { iे }\end{array}$ & 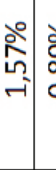 & 吾 & 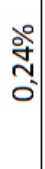 & & & & ठें \\
\hline 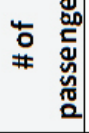 & m & 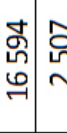 & 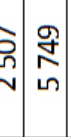 & 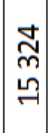 & $\begin{array}{l}\text { 出 } \\
\text { h }\end{array}$ & 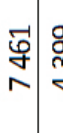 & 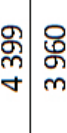 & 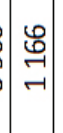 & $\begin{array}{l}\infty \\
: \\
: \\
N\end{array}$ & $\begin{array}{l}m \\
\vec{n} \\
-1\end{array}$ & 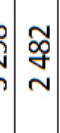 & 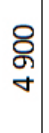 & 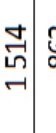 & : & $\widehat{\approx}$ & & & & 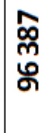 \\
\hline$\stackrel{\text { I. }}{=}$ & -1 & $N \mid m$ & $m+$ & 0 & $\infty$ & a) & 의 $=$ & $\approx$ & $m$ & $\exists \bar{n}$ & $\tilde{m}$ & $\stackrel{m}{m}$ & ঙे & $\hat{n}$ & ถี & กิ & & ○ & गु \\
\hline & & 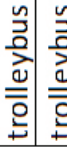 & 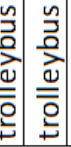 & 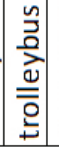 & & 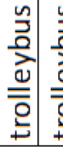 & 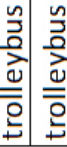 & 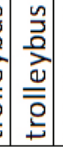 & 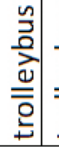 & 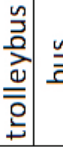 & & & & & & & & $\begin{array}{l}\hat{3} \\
\end{array}$ & \\
\hline
\end{tabular}

Table 7 illustrates the calculation of profit and profitability of individual bus and trolleybus lines. Column "revenues/costs" shows the percentage of the cost covered by the revenues. As we can see, only 5 lines out of 23 are able to cover its costs by the revenues. Municipal subsidies are included in the line revenues. Revenues, costs and profit volumes refers to annual volumes.

\section{DISCUSSION AND CONCLUSION}

Profitability analysis of the urban mass transport lines using Activity-Based Costing method bring number of specifics in comparison with traditional analysis in manufacturing industry. The major difference consists in the specific structure of the cost objects, i.e. the individual operated lines in our case which is different from tradi- 
tional cost objects such as individual products in case of manufacturing organizations. Despite the many problems that go with the application process, the ABC model is able to offer different view on the cost of activities and products inside the company. The ABC analysis, which we presented in this study, is relatively simple and does not apply to all ABC features, but could be accepted as the model example of further research in the field. On the other hand we have observed several limitations of the implemented ABC system. Firstly, most of the activity cost especially in main process had been assigned through the number of kilometers, which results in proportional assignment of the cost. In such design of the system, ABC application hadn't brought any significant benefits in comparison with more simple performance analysis.

Cost analysis based on ABC involves many information outcomes for decision making, such as eliminating the unprofitable cost objects (lines) or changes in the structure of operations. On the other hand, according to the municipal subsidies, the company couldn't be managed as the organization which is oriented to the profit generation. Company receives the municipal subsidies in order to operate the specific routes. Profit generated by the individual operated routes, which have been calculated in the study, then could not be used for the elimination of the unprofitable routes. $A B C$ in this situation could show the way how to reduce the loss generated by the less profitable routes or determine the impact of the different routes structure. Company, as the public transport operator, is also financially supported from the different EU fund schemes, especially in the field of purchasing new vehicles. Study also resulted in the analysis of profitability level of individual processes. This information is not new, because the existing cost center structure of the company, used before the $A B C$ application, allows the profit measurement. On the other hand $A B C$ brings more accurate way of support activity costs allocation. The many authors see the application of Activity-based costing method in service organization as the more usable, than in manufacturing industry. As mentioned above, the service organizations along with the urban mass transport providers face the many problems via application of effective costing system. Every additional piece of information which is provided by costing system could improve the quality of decision making and may lead into increase of performance and profitability of such organization.

\section{REFERENCES}

1) Andrade, M. C., Pessanha Filho, R. C., Espozel, A. M., Maia, L. O. A., \& Qassim, R. Y., (1999), Activity-based costing for production learning, International journal of production economics, 62(3), 175-180.

2) Baykasoglu, A., \& Kaplanoglu, V. (2007). A service-costing framework for logistics companies and a case study. Management Research News, 30(9), 621-633. Emerald Group Publishing.

3) De Borger, B., Kerstens, K., \& Costa, A. (2002). Public transit performance: What does one learn from frontier studies?. Transport reviews, 22(1), 1-38.

4) Drury, C. (2001). Management and Cost Accounting, 5th ed. Thomson Learning.

5) Everaert, P., Bruggeman, W., Sarens, G., Anderson, S., \& Levant, Y. (2008). Cost modeling in logistics using time-driven $A B C$ Experiences from a wholesaler. International Journal of Physical Distribution \&amp; Logistics Management, 38(3), 172-191. Emerald Group Publishing.

6) Everaert, P., Bruggeman, W., \& Sanac de Greus, G. (2008). From ABC to Timedriven $A B C$ (TDABC)-an instructional case. Journal of Accounting Education, 26(3),

7) Garrison, R.H., Noreen, E.W., \& Brewer, P.C. (2010). Managerial Accounting. New York: McGraw/lrwin.

8) Glad, E., \& Becker, H. (1996). Activity-Based Costing and Management. John Wiley and Sons.

9) Goldberg, M.J., \& Kosinski, L. (2011). Activity-based costing and management in a hospital-based GI unit. Clinical gastroenterology and hepatology , 9(11), 947-949. pmid:22018055

10) Hajek, O., \& Siwek, T. (2009). The perception of public city transport in Zlín (Czech Republic) as an alternative to individual transport by its potential users according to the level of their income. Moravian Geographical Reports, 17(1), 30-39.

11) Hankins, R.W., \& Baker, J. (2004). Management accounting for health care organi- 
sations. Tools and techniques for decision support. Sudbury, USA: Jones and Barlett Publisher.

12) Innes, M., \& Mitchell, F. (1990). Activity Based Costing: A review with case studies. London: Chartered institute of management accountants.

13) Kaplan, R., \& Johnson, H. (1987). Relevance lost: Rise and fall of management accounting. Boston: Harvard.

14) Král, B. (2006). Manažerské účetnictví. Praha: Management Press.

15) Lucey, T. (2002). Costing, 6th ed. United Kingdom: Thomson Learning.

16) Poliak, M. (2013). The relationship with reasonable profit and risk in public passenger transport in the Slovakia. Ekonomicky Casopis, Pages, 61(2), 206-220.

17) Pucher, J., Markstedt, A., \& Hirschman, I. (1983). Impacts of Subsidies on the Costs of Urban Public Transport. Journal of Transport Economics and Policy, 17(2), 155-176.
18) Rotch, W. (1990). Activity based costing in service industries. Journal of Cost Management, 4(2), 4-14.SDPCR - Sdružení dopravních podniků ČR Annual report, (2007).

19) Stouthuysen, K., Deeere, N., \& Roodhooft, F. (2009). Time-driven activity-based costing in an outpatient clinic environment: Development, relevance and managerial impact. Health Policy, 92(2-3), 296-304.

20) Tsai, W., \& Kuo, L. (2004). Operating costs and capacity in the airline industry. Journal of air transport management, Elsevier publishing, 10(4), 269-275.

21) Udpa, S. (1993). Activity-Based Costing for Hospitals. Health care management review, 21(3), Aspen Publishers.

22) Wodchis, W.P. (1999). Applying ActivityBased Costing in Long Term Care. Healthcare Management Forum, 11(4), 25-32.

Paper sent to revision: 18.02.2016.

Paper ready for publication: 05.09.2016. 